\title{
Meteorological fields variability over the Indian seas in pre and summer monsoon months during extreme monsoon seasons
}

\author{
U C Mohanty*, R Bhatla, P V S Raju, O P Madan and A Sarkar \\ Centre for Atmospheric Sciences, Indian Institute of Technology-Delhi, New Delhi 110 016, India. \\ \# Modi College of Engineering and Technology, Lakshamangarh, Sikar, Rajasthan, India. \\ *e-mail: mohanty@cas.iitd.ernet.in
}

In this study, the possible linkage between summer monsoon rainfall over India and surface meteorological fields (basic fields and heat budget components) over monsoon region $\left(30^{\circ} \mathrm{E}-120^{\circ} \mathrm{E}, 30^{\circ} \mathrm{S}-\right.$ $30^{\circ} \mathrm{N}$ ) during the pre-monsoon month of May and summer monsoon season (June to September) are examined. For this purpose, monthly surface meteorological fields anomaly are analyzed for 42 years (1958-1999) using reanalysis data of NCEP/NCAR (National Center for Environmental Prediction/National Center for Atmospheric Research). The statistical significance of the anomaly (difference) between the surplus and deficient monsoon years in the surface meteorological fields are also examined by Student's t-test at $95 \%$ confidence level.

Significant negative anomalies of mean sea level pressure are observed over India, Arabian Sea and Arabian Peninsular in the pre-monsoon month of May and monsoon season. Significant positive anomalies in the zonal and meridional wind (at $2 \mathrm{~m}$ ) in the month of May are observed in the west Arabian Sea off Somali coast and for monsoon season it is in the central Arabian Sea that extends up to Somalia. Significant positive anomalies of the surface temperature and air temperature (at $2 \mathrm{~m}$ ) in the month of May are observed over north India and adjoining Pakistan and Afghanistan region. During monsoon season this region is replaced by significant negative anomalies. In the month of May, significant positive anomalies of cloud amount are observed over Somali coast, north Bay of Bengal and adjoining West Bengal and Bangladesh. During monsoon season, cloud amount shows positive anomalies over NW India and north Arabian Sea.

There is overall reduction in the incoming shortwave radiation flux during surplus monsoon years. A higher magnitude of latent heat flux is also found in surplus monsoon years for the month of May as well as the monsoon season. The significant positive anomaly of latent heat flux in May, observed over southwest Arabian Sea, may be considered as an advance indicator of the possible behavior of the subsequent monsoon season. The distribution of net heat flux is predominantly negative over eastern Arabian Sea, Bay of Bengal and Indian Ocean. Anomaly between the two extreme monsoon years in post 1980 (i.e., 1988 and 1987) shows that shortwave flux, latent heat flux and net heat flux indicate reversal in sign, particularly in south Indian Ocean. Variations of the heat budget components over four smaller sectors of Indian seas, namely Arabian Sea, Bay of Bengal and west Indian Ocean and east Indian Ocean show that a small sector of Arabian Sea is most dominant during May and other sectors showing reversal in sign of latent heat flux during monsoon season.

Keywords. Summer monsoon; heat budget components; NCEP reanalysis; Student's t-test. 


\section{Introduction}

The Indian summer monsoon (June to September) contributes $80 \%$ of the annual rainfall of the country. The Indian summer monsoon rainfall shows large annual variability. It is well known that the tropical sea/ocean acts as the main reservoir of heat and moisture. It provides the necessary energy to drive the large-scale summer monsoon and the associated rainfall over the Indian sub-continent. Therefore, it is important to understand the air-sea interaction processes over the tropical ocean and its association with Indian summer monsoon activity. Experiments such as the Indian Ocean Experiment (IIOE), 1964-1965, Indo Soviet Monsoon Experiment (ISMEX), 1973, MONSOON-77, 1977 and Monsoon Experiment (MONEX), 1979 had been organized to examine the role of the ocean in the variability of Indian summer monsoon. In recent years, the Indian Ocean Experiment (INDOEX), 1998-1999 and Bay of Bengal Monsoon Experiment (BOBMEX), 1999 have been organized to study the dynamics of atmosphere-ocean interaction.

Pisharoty (1965); Das (1983); Mohanty et al (1983), and Mohanty and Mohan Kumar (1990) showed the importance of the energy fluxes over the Indian seas during different epochs of the summer monsoon activity over India. Shukla (1975, 1987); Weare (1979); Rao and Goswami (1988) showed the possible relationship between sea surface temperature variations over different parts of the Indian Ocean and monsoon activity over the Indian subcontinent. Mohanty and Ramesh (1993) studied sea surface temperature and sea level pressure and concluded that they do not show significant variability over the Indian Ocean between extreme categories (surplus and deficient) of monsoon. However, the wind, cloud and humidity, which determine the transfer of heat and moisture fluxes from ocean to the atmosphere, show significant variability in large excess and deficient monsoon rainfall years. Mohanty et al (1994) discussed in their study that it is important to understand the connection between the air-sea fluxes and monsoon activity rather than the SST anomaly and the monsoon activity. Mohanty et al (1996) examined the oceanic heat budget components and their variability over the Indian Ocean in relation to the extreme monsoon activity (flood/drought) over the Indian subcontinent using Comprehensive Oceanic and Atmospheric Data Set (COADS) for the year 1950-1979. Manabe et al (1975) showed that these fluxes act as lower boundary condition for the atmosphere and as an upper boundary condition for the ocean in the large scale coupled model. Mohanty and Mohan Kumar (1990) using MONEX-79 data showed that air-sea fluxes of heat and moisture play an important role in relating the marine boundary layer fluxes and the monsoon. Saji et al (1999) showed a dipole mode in the Indian Ocean using 40 years data having a pattern of internal variability with anomalously low sea surface temperature at Sumatra and high sea surface temperature in the western Indian Ocean. Kumar et al (1999) suggest that the inverse relationship between El Nino Southern Oscillation (ENSO) and the Indian summer monsoon has broken down in the recent decades using the 140-year historical record.

In the present study, an attempt has been made to examine the linkage of surface meteorological fields (basic fields and heat budget components) with monsoon activity over India for a recent period of 42 years (1958-1999) using NCEP/NCAR reanalysis data set.

\section{Data and analysis procedure}

One of the reliable and homogenous global circulation data set recently available is the NCEP/NCAR (National Center for Environmental Prediction/National Center for Atmospheric Research), USA reanalysis data set that has been used in the present study. This data set is a result of the joint efforts of the NCEP, formerly known as NMC (National Meteorological Center) and the NCAR, to produce a 42-year (1958-1999) record of global analysis of the atmospheric fields. The effort involves the recovery of land surface, ship, rawinsonde, aircraft, satellite data and delayed mode GTS data its quality control and assimilation with four dimensioned data assimilation system that is kept unchanged over the entire period (Kalney et al 1996).

Based on Parthasarthy et al (1994), the all India summer monsoon rainfall data, the 42-year period (1958-1999) has been divided into three categories of normal, surplus and deficient monsoon rainfall years (table 1). The year is classified as deficient (drought) rainfall year, when the all India seasonal rainfall is lower by 10 per cent or more from the long term mean. Similarly, when the rainfall is higher by 10 per cent or more from the longterm mean, it is classified as surplus (flood) rainfall year. The remaining years are categorised as normal years. Thus, out of the 42-year data, 7 years have been found to be surplus and 10 years to be deficient and the remaining 25 years are categorised as normal (table 1).

The domain examined in the present study extends from $30^{\circ} \mathrm{S}$ to $30^{\circ} \mathrm{N}$ and $30^{\circ} \mathrm{E}$ to $120^{\circ} \mathrm{E}$, that consists of the major oceanic and land regions under the influence of the monsoon regime. The average of surface meteorological fields i.e., basic 
Table 1. Surplus and deficient monsoon years for the period 1958-1999.

\begin{tabular}{cc}
\hline Surplus monsoon years & Deficient monsoon years \\
\hline 1959 & 1965 \\
1961 & 1966 \\
1970 & 1968 \\
1975 & 1972 \\
1983 & 1974 \\
1988 & 1979 \\
1994 & 1982 \\
& 1985 \\
& 1986 \\
\hline
\end{tabular}

fields (mean sea level pressure, zonal and meridional wind at $2 \mathrm{~m}$, surface and air temperature at $2 \mathrm{~m}$, cloud amount) and heat budget components (shortwave radiation flux, longwave radiation flux, sensible heat flux, latent heat flux, net heat flux) for surplus and deficient monsoon years were computed for the month of May as well as the following monsoon season. The anomalies of surface meteorological fields between the two extreme categories of the monsoon (surplus and deficient) have been tested for their significance using Student's t-test. The anomalies with $95 \%$ level of confidence are shaded in all anomalies results (figures 2 to 4 ). In order to examine the applicability of the study of Kumar et al (1999), we have taken the anomaly of 1961 (surplus) and 1972 (deficient) before 1980 and anomaly of 1988 (surplus) and 1987 (deficient) post 1980 to observe whether heat fluxes over the Indian Ocean also show any prominent changes post 1980 . The study also includes the variations of mean monthly values of dominant heat budget components in the surplus and deficient monsoon years averaged over the four selected sectors (figure 1) namely the Arabian Sea (Box 1), Bay of Bengal (Box 2), west Indian Ocean (Box 3) and over the east Indian Ocean (Box 4) as shown in figure 1.

The present paper includes the larger data set as compared to COADS data sets for the period 19491979 used by Mohanty et al (1994). Moreover, the present data sets (1958-1999) would contain the satellite-derived parameters for post 1980 period, which were not present in the COADS data sets used in early study by Mohanty et al. This also prompted us to examine the anomalies in the pre and post satellite periods in the extreme events of summer monsoon. Further, Kumar et al (1999) had

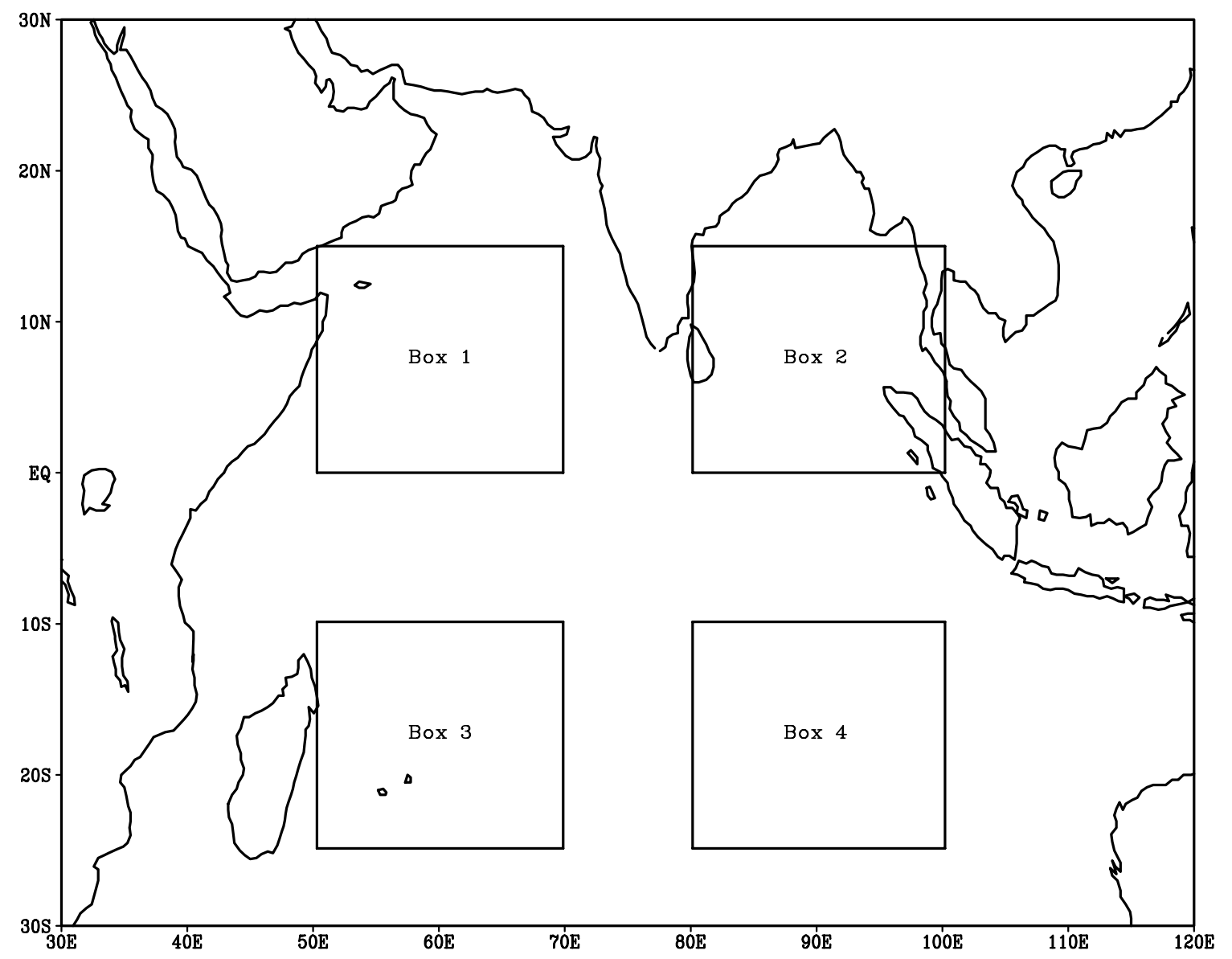

Figure 1. Geographical boundaries of the region of study with four oceanic sectors. Box 1: Arabian Sea, Box 2: Bay of Bengal, Box 3: west Indian Ocean and Box 4: east Indian Ocean. 
brought out that ENSO-monsoon relationship has almost broken down in recent decades (i.e., post 1980 period) and Saji et al (1999) show the dipole mode in the Indian Ocean. Both these studies indicate the important role of SST and its variation over the Indian seas. The SST and its variation affect air sea fluxes. Hence, it became advisable to carry out the present study with recent data sets and examine the role of oceanic fluxes on monsoon variability over India.

To compare the net balance of the radiative and turbulent fluxes of heat and moisture at the air-sea interface, the net heat budget equation $\left(\mathrm{Wm}^{-2}\right)$ can be written as

$$
Q_{N}=Q_{R}-Q_{B}-Q_{H}-Q_{E}
$$

where $Q_{N}$ is the net heat flux $\left(\mathrm{Wm}^{-2}\right), Q_{R}$ is the incoming shortwave radiation flux $\left(\mathrm{Wm}^{-2}\right), Q_{B}$ is the effective outgoing longwave radiation flux $\left(\mathrm{Wm}^{-2}\right), Q_{H}$ is the sensible heat flux $\left(\mathrm{Wm}^{-2}\right)$, and $Q_{E}$ is the latent heat flux $\left(\mathrm{Wm}^{-2}\right)$. In the above budget equation, $Q_{R}$ contributes significantly to the oceanic heat gain whereas the other terms contribute towards the heat loss from tropical oceanic surfaces. In the present study, daily values of $Q_{R}, Q_{B}, Q_{H}$ and $Q_{E}$ at $00,06,12,18$ UTC for each grid point are directly taken from the NCEP/NCAR reanalysis and averages computed for each month and season. Since the advection of heat maintains long-term balance on a climatic scale, it has not been considered in this study.

Though the re-analysis values of NCEP are considered reasonable, they could differ from estimates done by other workers. Therefore, a comparison was done with other in situ estimates such as Southampton Oceanographic Center (SOC data set Josey et al 1999) and satellite estimates, Hamburg Ocean Atmosphere Parameters and fluxes from satellite data sets (HOAPS, Grassl et al 2000). It is observed that sensible heat flux and long wave flux of NCEP nearly match with those of SOC and HOAPS estimates. However, latent heat flux estimate by NCEP is slightly higher in the Indian seas. Since the present study involves differences in the various fluxes of energy of excess and deficient monsoon years, minor differences in the magnitudes observed in various estimates is not likely to change the course of results and hence use of the NCEP re-reanalysis in the study is considered appropriate.

\section{Results and discussion}

The anomalies of surface meteorological fields were examined for the pre-monsoon month of May as well as the summer monsoon season (JuneSeptember). The effective longwave radiation flux and sensible heat flux showed no significant variations in the month of May as well as in the following monsoon season for the two extreme categories of monsoon. Therefore, the variations of longwave radiation flux and sensible heat flux in the present study have not been discussed. The anomalies in respect of other fields are discussed as under.

\subsection{Variations of the surface meteorological fields and dominant heat budget components anomalies}

\subsubsection{Mean sea level pressure}

Figure 2(a) and (d) show the distribution of mean sea level pressure anomalies with t-test of significance at $95 \%$ confidence level for the month of May and the monsoon season respectively. Figure 2(a) shows significantly lower pressure of $1 \mathrm{hPa}$ to $2 \mathrm{hPa}$ covering a major part of India, Arabian Sea, Arabia and part of north Africa. In the monsoon months significant negative anomalies of $1 \mathrm{hPa}$ to $1.5 \mathrm{hPa}$ are observed over most of the domain of the Indian Ocean (figure 2d). Thus, the mean sea level pressure in surplus years is significantly lower in the pre-monsoon month of May as well as in the monsoon season by $1 \mathrm{hPa}$ to $2 \mathrm{hPa}$.

\subsubsection{Surface wind}

The zonal wind (at $2 \mathrm{~m}$ ) anomaly distribution for the month of May and the monsoon season along with t-test of significance is shown in figure 2(b) and figure 2(e) respectively. In the month of May, the zonal wind anomalies off Somali coast and southwest Arabian Sea are positive and significant (figure $2 \mathrm{~b}$ ). It indicates that strong westerlies develop in the west Arabian Sea in the month of May during surplus monsoon years. Significant negative anomalies of $0.5 \mathrm{~ms}^{-1}$ to $1.0 \mathrm{~ms}^{-1}$ are observed over Gangetic West Bengal, Arabia and parts of south Indian Ocean (figure 2b). Negative anomalies over Gangetic West Bengal indicate the establishment of an early and deeper monsoon trough line in May. In the monsoon season (JJAS) significant positive anomalies $0.5 \mathrm{~ms}^{-1}$ to $1 \mathrm{~ms}^{-1}$ extend from Somali coast to west coast of India associated with stronger Somali jet. Significant negative anomalies are observed over the equatorial Indian Ocean, southwest Indian Ocean and Indo-Gangetic plane. The negative anomalies over the Indian Ocean are due to stronger southeast trades in monsoon months in the surplus monsoon years. Similarly, persistence of negative anomalies 
May
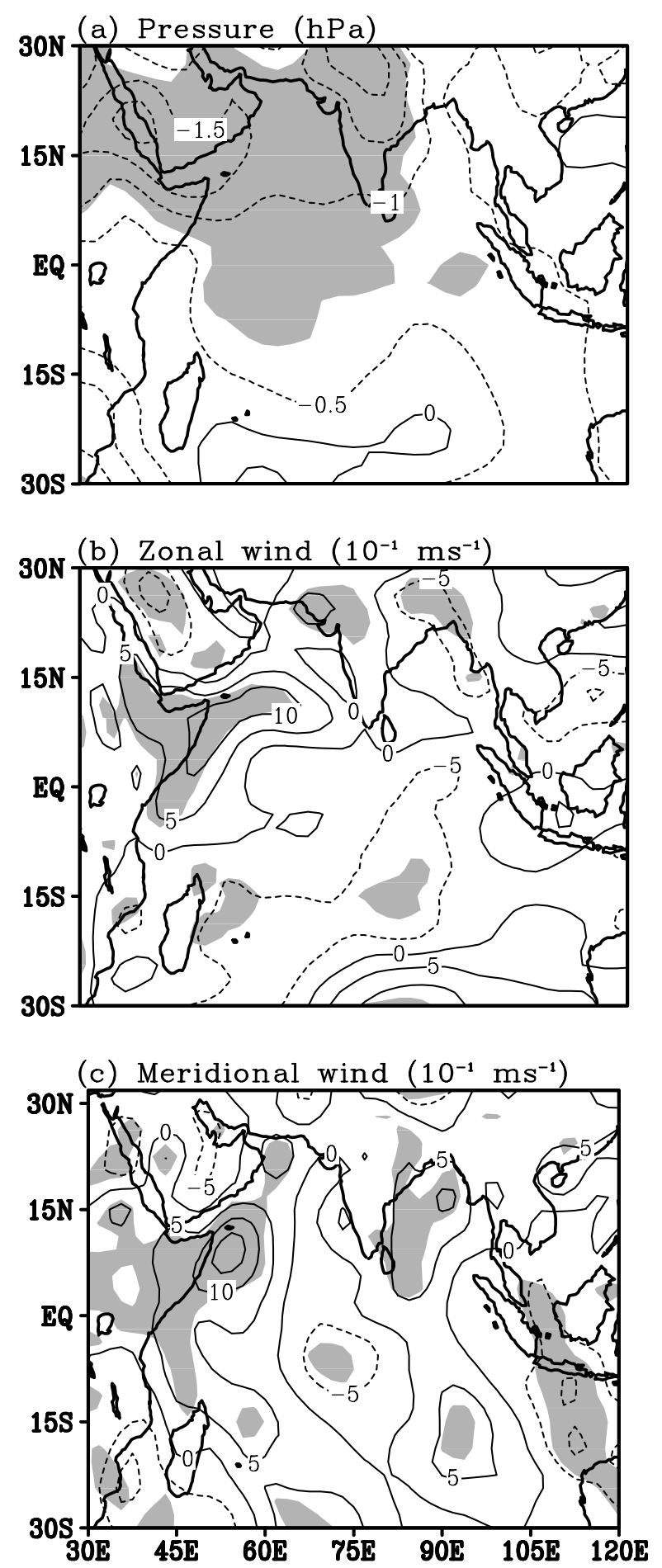

JJAS
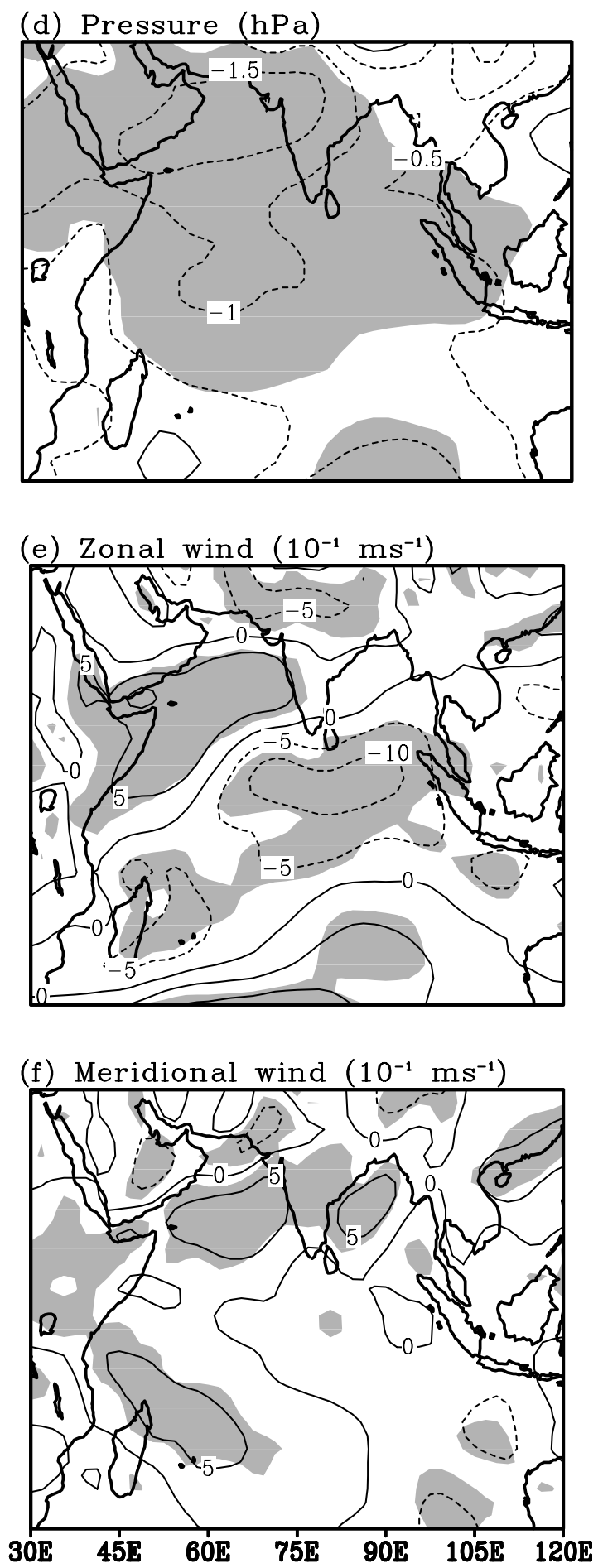

Figure 2. Distributions of anomaly of (a) mean sea level pressure (hPa) (b) zonal wind $\left(10^{-1} \mathrm{~ms}^{-1}\right)$ (c) meridional wind $\left(10^{-1} \mathrm{~ms}^{-1}\right)$ during May and (d), (e) and (f) are same as (a), (b) and (c) but for monsoon season (JJAS) with confidence limit above $95 \%$ (shaded).

over the Indo-Gangetic plane in the monsoon season indicates the greater strength and persistence of the monsoon trough line in the surplus years.

Figure 2(c) and (f) show the distribution of meridional wind (at $2 \mathrm{~m}$ ) anomalies during the month of May and the monsoon season respectively. The month of May shows significant positive anomaly varying between $0.5 \mathrm{~ms}^{-1}$ and $1.5 \mathrm{~ms}^{-1}$ extending from Madagascar Island and proceeding along the Somali coast to the north Arabian Sea. 
May

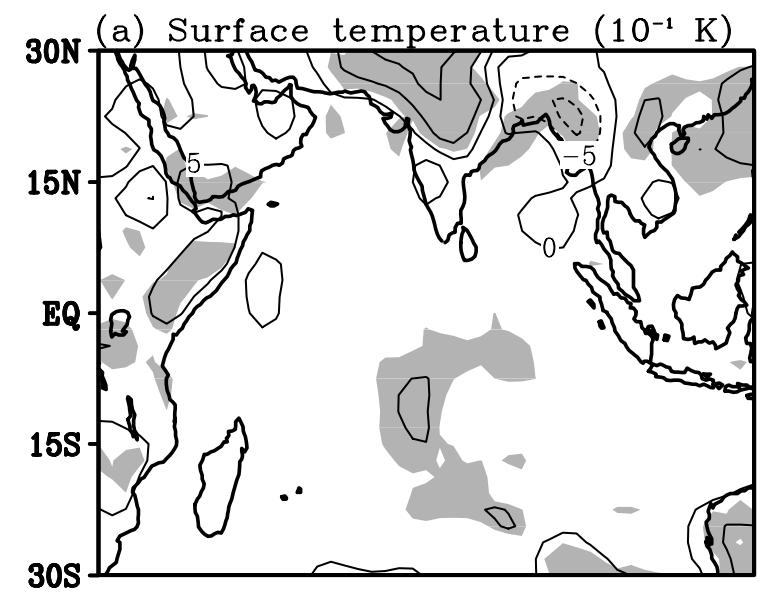

(b) Air temperature at $2 \mathrm{~m}\left(10^{-1} \mathrm{~K}\right)$

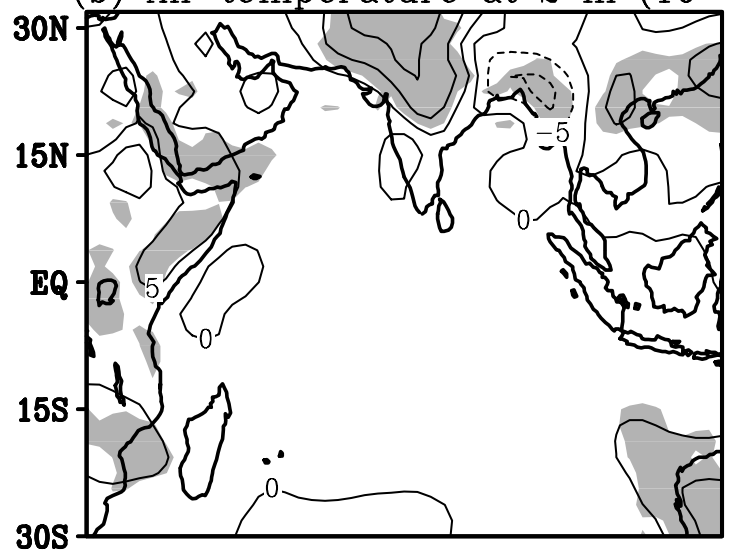

(c) Cloud amount $\left(10^{-1}\right.$ Octa)

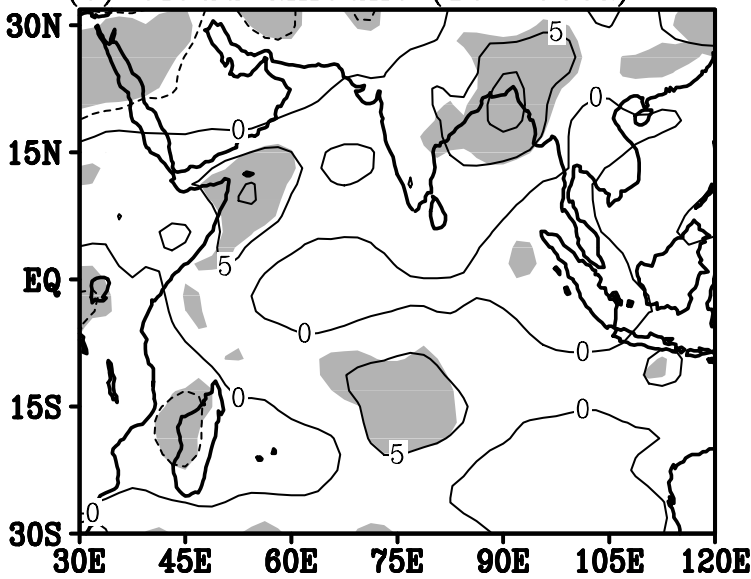

JJAS

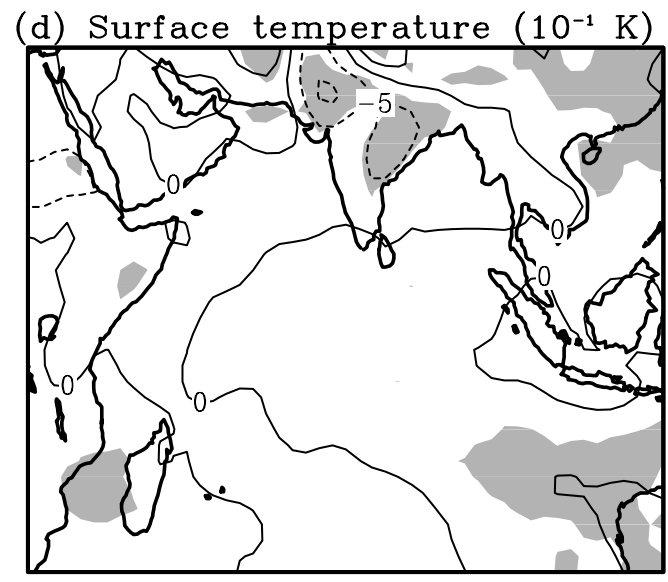

(e) Air temperature at $2 \mathrm{~m}\left(10^{-1} \mathrm{~K}\right)$
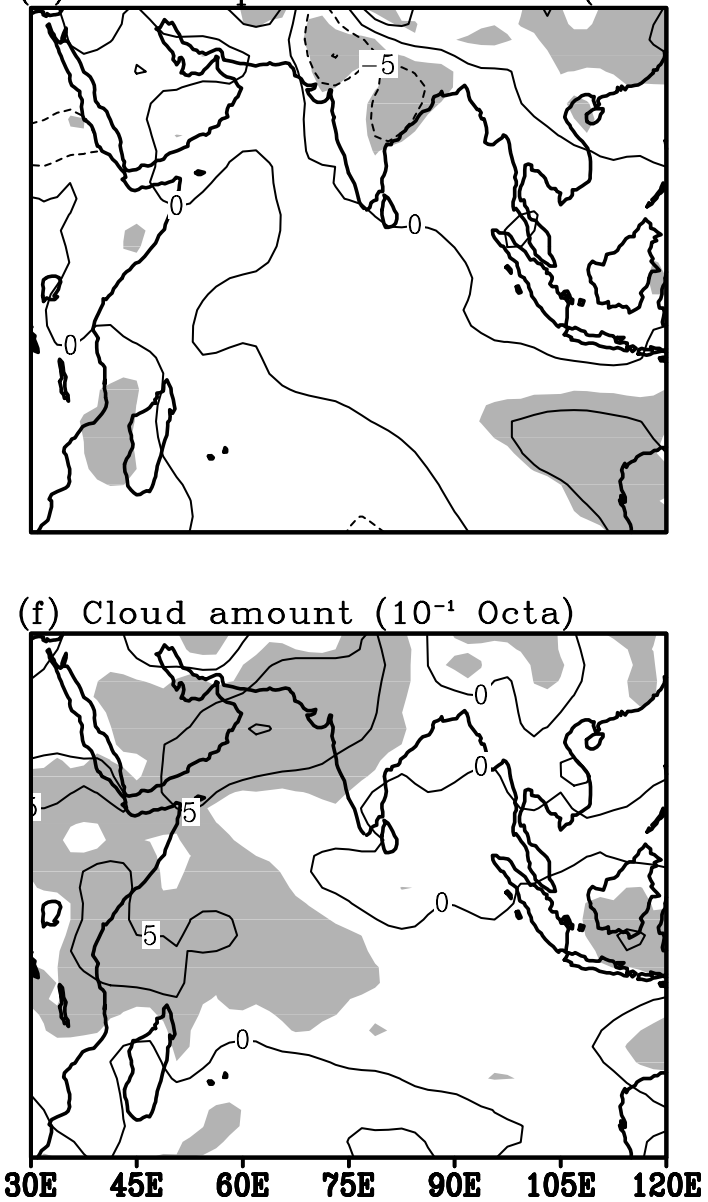

Figure 3. Distributions of anomaly of (a) surface temperature $\left(10^{-1} \mathrm{~K}\right)$ (b) air temperature at $2 \mathrm{~m}\left(10^{-1} \mathrm{~K}\right)$ (c) total cloud cover $\left(10^{-1}\right.$ Octa) during May and (d), (e) and (f) are same as (a), (b) and (c) but for monsoon season (JJAS) with confidence limit above 95\% (shaded).

Significant positive anomalies of $0.5 \mathrm{~ms}^{-1}$ to $1 \mathrm{~ms}^{-1}$ are also observed in the western Bay of Bengal extending from Srilanka to northeast Bay (figure 2c). Significant southerlies at the surface in the month of May indicate prevalence of northward transport, which in the present case could mean moisture transport. In the monsoon months the southerly anomalies of $0.5 \mathrm{~ms}^{-1}$ extend from southwest Indian Ocean along Madagascar across Kenya to the Arabian Sea, central India, central and north 
Bay (figure 2f). The stronger southerlies in the monsoon months of surplus years indicate higher northward transport of air in the Arabian Sea and Indian Ocean.

\subsubsection{Surface and air temperature}

Figure 3(a) and (d) depict the distribution of surface temperature anomaly for the month of May and the monsoon season respectively. In the month of May significant warmer temperature from $1.5 \mathrm{~K}$ to $2 \mathrm{~K}$ are observed over complete northwest India (figure 3a). The northeastern Indian region shows cooler temperature of $0.5^{\circ} \mathrm{K}$ to $1.0^{\circ} \mathrm{K}$. The positive anomaly over northwest India is due to excess heating and the negative anomaly is due to excess clouding and possibly precipitation over northeast India and pre-monsoon thunderstorm activity over the region. In the monsoon season significant negative anomalies are observed over the complete Indo-Gangetic plane indicating less insolation possibly due to higher clouding and precipitation in surplus years (figure 3d). Figure 3(b) and (e) show the distribution of air temperature (at $2 \mathrm{~m}$ ) for the month of May and monsoon season respectively. It shows a similar pattern as in surface temperature.

\subsubsection{Total cloud cover}

The distribution of total cloud cover for the month of May and the monsoon season is shown in figure 3(c) and (f) respectively. In the month of May significant positive anomaly of cloud amount varying between 0.5 Octa and 1 Octa are observed in the western Arabian Sea off Somali coast, north Bay of Bengal, adjoining parts of Orissa, West Bengal and Bangladesh (figure 3c). Significant positive anomalies are also observed in part of the south Indian Ocean (figure 3c). In the monsoon months significant positive anomalies of 0.5 Octa to 1 Octa are observed extending from southwest Indian Ocean across Somalia, Kenya, Arabian Peninsula, north Arabian Sea to northwestern parts of India (figure 3f). The positive anomalies indicate that southeast trades in the southern hemisphere are stronger in the surplus years and are associated with higher cloudiness. After crossing the equator they become southwesterly and maintain their strength and vigor.

\subsubsection{Shortwave radiation flux}

The distribution of the average of incoming shortwave radiation flux at surface (SWF) anomalies during May and the monsoon season are shown in figure 4(a) and (d) respectively. Figure 4(a) shows the significant negative anomaly over the north Bay of Bengal, southwest Arabian Sea off Somali coast and part of south Indian Ocean. The significant negative anomalies are in consonance with the total cloud cover observed in figure 3(c). In the monsoon season the significant negative anomaly of SWF (figure 4d) is observed in the NE-SW oriented band extending from Gangetic West Bengal to northwest India to Arabia through north Arabian Sea. The broken band of significant negative anomaly is also observed over southwest Indian Ocean located between $5^{\circ} \mathrm{N}$ and $15^{\circ} \mathrm{S}$. The negative anomaly is due to higher prevalence of cloud cover in the surplus monsoon years as is evident from figure $3(\mathrm{f})$.

\subsubsection{Latent heat flux}

Figure 4(b) and (e) depict the distribution of average latent heat flux (LHF) anomaly during May and the monsoon season respectively. The distribution of LHF anomaly shows a region of significant positive anomaly over the southwestern sector of the Arabian Sea off Somali coast (figure $4 \mathrm{~b}$ ). The significant positive anomaly of LHF in May over southwest Arabian Sea is expected due to higher surface wind and higher air-sea temperature contrast in those areas. Since low level wind strength is an important parameter in LHF, it is quite probable that location and intensity of Mascrene's high and the associated cross equatorial wind are responsible for the variations in LHF during the pre-monsoon month of May of surplus and deficient monsoon years. During the summer monsoon season, the LHF anomaly shows significant positive anomaly over parts of the Arabian Sea. Another region of significant positive anomaly is found in the south Indian Ocean, particularly over and to the east of Madagascar (figure 4e). Stronger southeast trades in the southern hemisphere during monsoon months appear to be associated with the positive anomalies in the south Indian Ocean.

\subsubsection{Net heat flux}

Figure 4(c) and (f) illustrate the geographical distribution of average net heat flux anomaly for the month of May and the monsoon season respectively. During May (figure 4c) significant negative anomalies (heat loss) are found in the southwest Arabian Sea off Somali coast, north Bay of Bengal and some areas of south Indian Ocean. The negative anomalies (oceanic heat loss) are mainly attributed to strong low level wind and enhanced evaporation, leading to upwelling, cooling of sea surface and enhanced pre-monsoon convective activity with more cloud cover and reduction of incoming short-wave radiation. The results in the pre-monsoon month of May confirm 

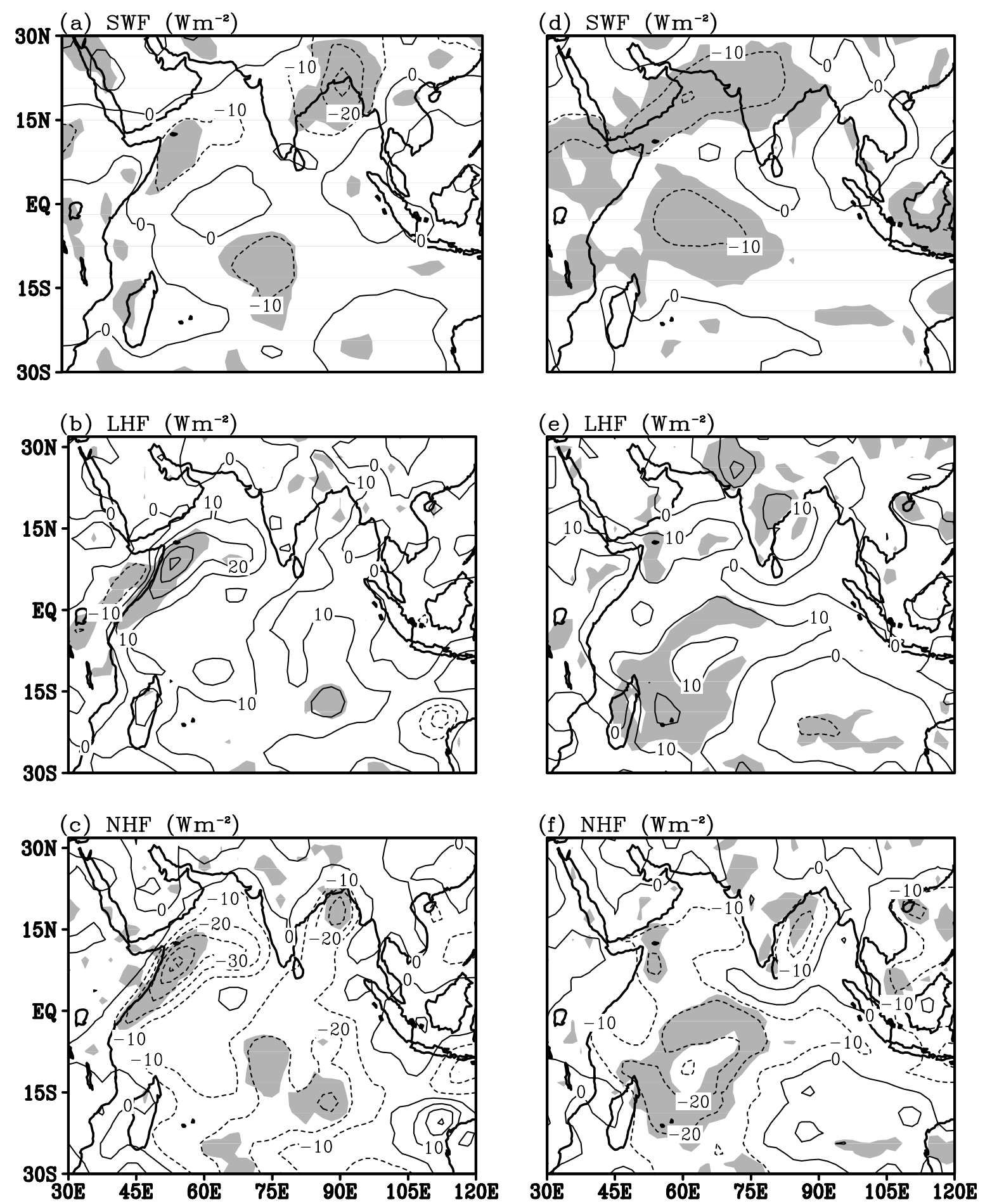

Figure 4. Distributions of anomaly of (a) shortwave radiation $\left(\mathrm{Wm}^{-2}\right)$ (b) latent heat flux $\left(\mathrm{Wm}^{-2}\right)(\mathbf{c})$ net heat flux $\left(\mathrm{Wm}^{-2}\right.$ ) during May and (d), (e) and (f) are same as (a), (b) and (c) but for monsoon season (JJAS) with confidence limit above $95 \%$ (shaded).

an earlier study by Mohanty et al (1996) and serve as a useful predictor for the subsequent monsoon season rainfall activity.

Negative NHF anomaly is observed over the western sector of Arabian Sea, northwest Bay of
Bengal and southwest Indian Ocean (figure 4f). The possible reason could be the reduction in SWF together with increased LHF during the summer monsoon season leading to the development of significant heat loss region. It clearly shows that sur- 


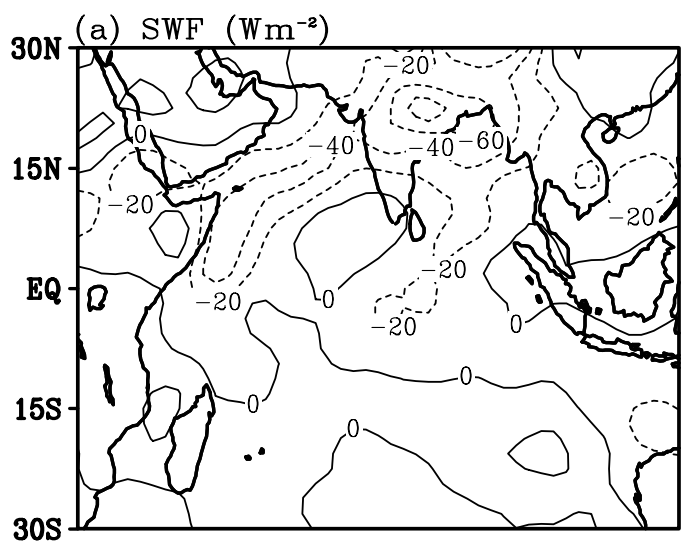

(d) SWF $\left(\mathrm{Wm}^{-2}\right)$

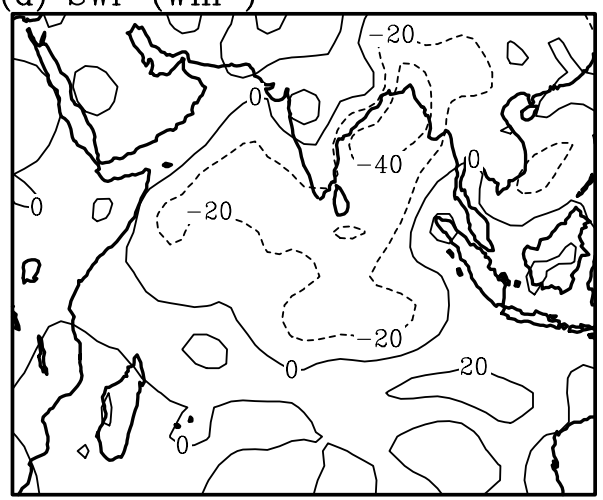

(b) LHF $\left(\mathrm{Wm}^{-2}\right)$

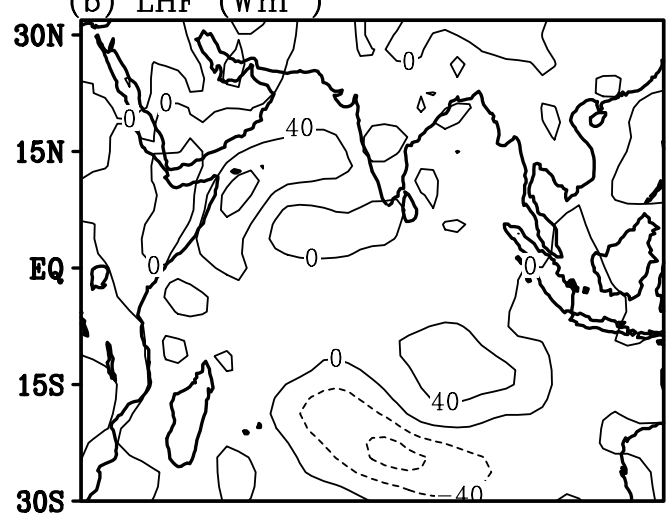

(e) $\operatorname{LHF}\left(\mathrm{Wm}^{-2}\right)$

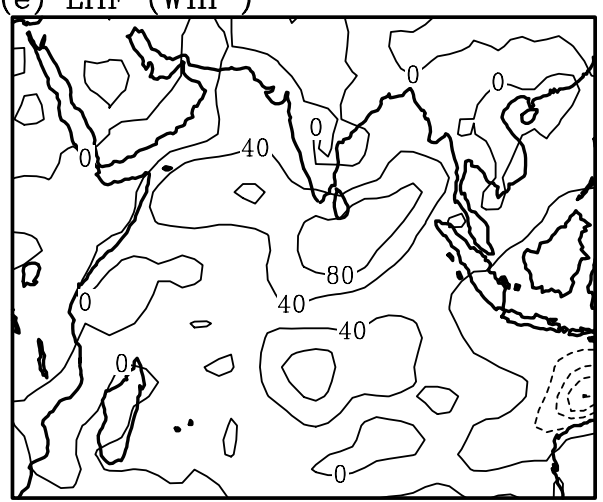

(c) $\mathrm{NHF}\left(\mathrm{Wm}^{-2}\right)$

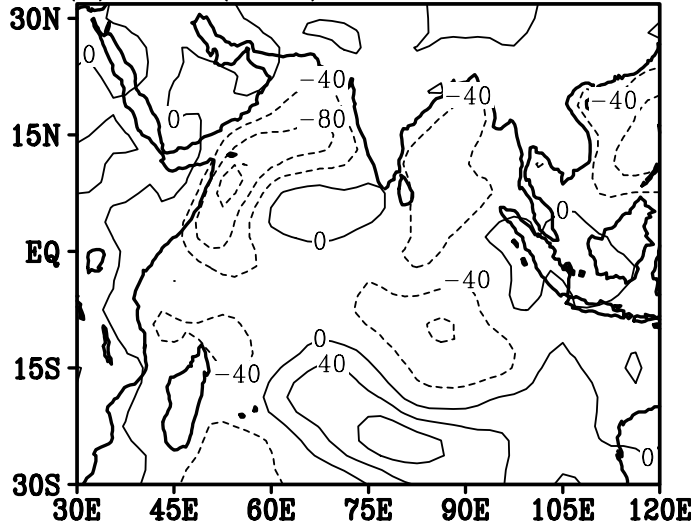

(f) $\mathrm{NHF}\left(\mathrm{Wm}^{-2}\right)$

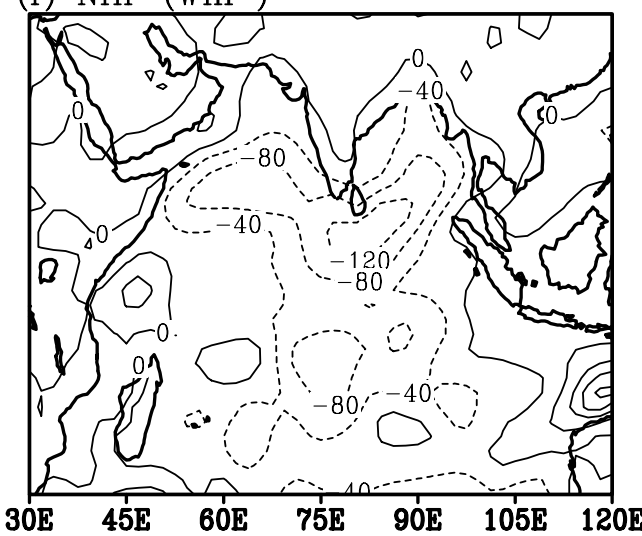

Figure 5. Distributions of anomalies during May between the year of most excess rainfall (1961) and year of most deficient rainfall (1972) for (a) shortwave radiation $\left(\mathrm{Wm}^{-2}\right)$ (b) latent heat flux $\left(\mathrm{Wm}^{-2}\right)$ (c) net heat flux $\left(\mathrm{Wm}^{-2}\right) \mathrm{during}_{\mathrm{May}}$ and (d), (e) and (f) are same as (a), (b) and (c) but for anomalies of 1988 and 1987.

plus years are associated with larger heat loss from the ocean to atmosphere and lower heat loss in deficient monsoon years over the Arabian Sea.

\subsection{Anomaly of the dominant heat budget components between the most excess and most deficient monsoon year}

The difference of the fields of SWF, LHF and NHF for the year of most excess rainfall (1961) and year of most deficient rainfall (1972) prior to the year 1980 over India are examined during the premonsoon month of May and depicted in figure $5(\mathrm{a}, \mathrm{b}, \mathrm{c})$ respectively. Similarly, anomaly of the fields of SWF, LHF and NHF for the year of most excess rainfall (1988) and year of most deficient rainfall (1987) post 1980 are depicted in figure $5(\mathrm{~d}, \mathrm{e}, \mathrm{f})$ respectively. Figure 5(a) shows maximum negative difference of SWF over north Arabian Sea off Somalia and in the monsoon trough zone 

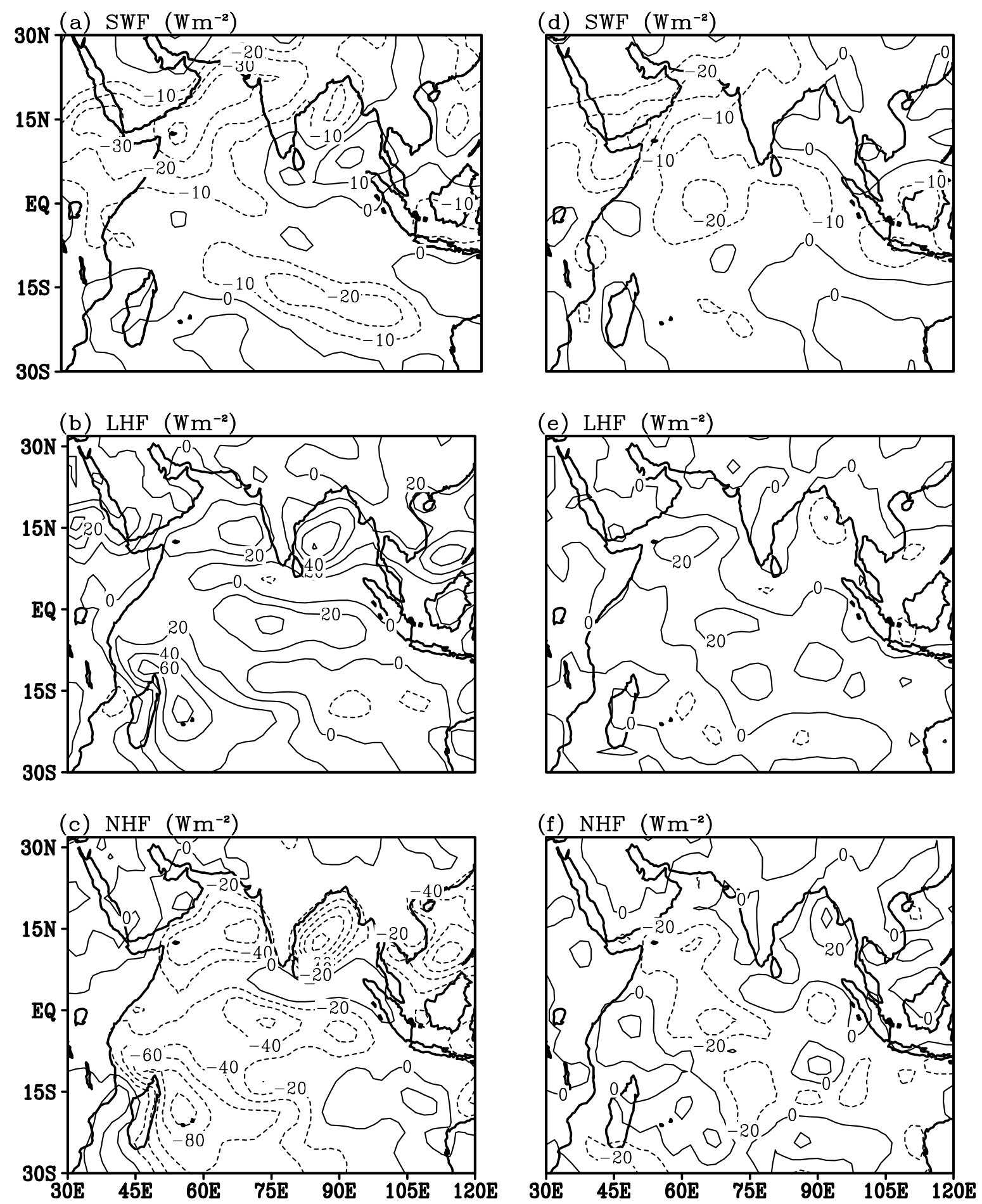

Figure 6. Same as figure 5 but for monsoon season (JJAS).

over India. The anomalies vary between 40 and 80 $\mathrm{Wm}^{-2}$. The difference of 1988 and 1987 (figure 5d) shows a shift in the pattern eastwards. Positive anomalies in both the cases are observed in the south Indian Ocean, while the post 1980 anomalies are higher in the eastern parts. One of the possible reasons for the difference in the two difference fields could be the relative strength of monsoon in different years or internal variability.

The difference (1961 and 1972) of LHF (figure 5b) shows the maximum positive difference over Arabian Sea off Somalia. It also shows the negative difference over the region around $15^{\circ} \mathrm{S}$ to $30^{\circ} \mathrm{S}, 60^{\circ} \mathrm{E}$ to $90^{\circ} \mathrm{E}$. Figure $5(\mathrm{e})$ shows the LHF dif- 
ference of 1988 and 1987. There are some differences in two patterns. Firstly, the maxima of the positive LHF difference has shifted eastwards to south Bay of Bengal and adjoining north Indian Ocean as in the case of SWF. Secondly, the negative LHF difference in the south Indian Ocean has been replaced by a small positive LHF difference, but in the southeastern parts the positive anomalies have enhanced.

The difference of 1961 and 1972 of NHF (figure 5c) shows maximum negative difference over SW Arabian Sea off Somalia, Bay of Bengal and positive difference over Indian Ocean around $15^{\circ} \mathrm{S}$ to $30^{\circ} \mathrm{S}, 60^{\circ} \mathrm{E}$ to $90^{\circ} \mathrm{E}$. The difference of 1988 and 1987 for NHF (figure 5f) shows maximum negative difference over south Bay of Bengal and north Indian Ocean. The pattern shows eastward shift like SWF and LHF in post 1980 year. In the south Indian Ocean also there is reversal in the pattern in the region $15^{\circ} \mathrm{S}$ to $30^{\circ} \mathrm{S}, 60^{\circ} \mathrm{E}$ to $90^{\circ} \mathrm{E}$.

The difference of the fields of SWF, LHF and NHF during the monsoon season (JJAS) for the year of most excess rainfall (1961) and year of most deficient rainfall (1972) before the year 1980 over India is shown in figure $6(\mathrm{a}, \mathrm{b}, \mathrm{c})$. Similar difference fields for the year of most excess rainfall (1988) and year of most deficient rainfall (1987) post 1980 are shown in figure $6(\mathrm{~d}, \mathrm{e}, \mathrm{f})$. The maximum negative anomalies of SWF prior to 1980 are found over Arabian Sea, north Bay of Bengal, south and southeast Indian Ocean (figure 6a). A zone of large positive SWF difference lies over SE Bay of Bengal off Indonesia (figure 6a). Difference of 1988 and 1987 (figure 6d) shows a similar pattern as in the difference of 1961 and 1972 (figure 6a) for Arabian Sea. However, for the Bay of Bengal and south, southeast Indian Ocean, the pattern is reversed, which is an interesting departure between pre and post 1980 .

Figure 6(b) shows the difference of LHF for the two extreme monsoon years of 1961 and 1972. It shows that the maximum positive LHF anomalies are observed over Arabian Sea, Bay of Bengal, north Indian Ocean and south Indian Ocean particularly off Madagascar. The difference of the year 1988 and 1987 (figure 6e) differs significantly from the difference of the year 1961 and 1972 (figure 6b) in the Bay of Bengal and south Indian Ocean off Madagascar where anomalies are weakly negative.

The difference in the field of the NHF in the two most extreme monsoon years 1961 and 1972 during the seasons prior to 1980 is characterized by overall net heat loss (large negative NHF differences) over the Arabian Sea, Bay of Bengal north and south equatorial Indian Ocean (figure 6c). Figure 6(f) (difference of the years 1988 and 1987) shows a negative NHF difference over central Arabian Sea and part of equatorial Indian Ocean. The Bay of Ben- gal and south Indian Ocean region off Madagascar in the Indian Ocean shows the net heat gain (positive NHF difference) (figure 6f). Thus, the region of Bay of Bengal and south Indian Ocean shows reversal in pattern post 1980 .

The shift of the pattern in anomalies of SWF, LHF and NHF during May and the monsoon season eastwards in post 1980 event i.e., difference between 1988 and 1987 could possibly be due to internal variability caused by variation of low sea surface temperature and associated southeast trades as indicated by Saji et al (1999). It could also be possibly due to improved data sets with the addition of data from satellites and other sources post 1980 .

\subsection{Variations of difference of dominant heat budget components over different sectors of Indian Ocean}

The variation of difference of SWF, LHF and NHF during May and the monsoon season (JJAS) are studied over four oceanic sectors namely Arabian Sea, Bay of Bengal, west Indian Ocean and east Indian Ocean. The geographical boundaries of these oceanic sectors, as shown in figure 1 are given below:

- Arabian Sea (Box 1), Eq. $-15^{\circ} \mathrm{N}, 50^{\circ} \mathrm{E}-70^{\circ} \mathrm{E}$.

- Bay of Bengal (Box 2), Eq. $-15^{\circ} \mathrm{N}, 80^{\circ} \mathrm{E}-100^{\circ} \mathrm{E}$.

- Western south Indian Ocean (Box 3), $10^{\circ} \mathrm{S}-$ $25^{\circ} \mathrm{S}, 50^{\circ} \mathrm{E}-70^{\circ} \mathrm{E}$.

- Eastern south Indian Ocean (Box 4), $10^{\circ} \mathrm{S}$ $25^{\circ} \mathrm{S}, 80^{\circ} \mathrm{E}-100^{\circ} \mathrm{E}$.

Figure $7(\mathrm{a}, \mathrm{b}, \mathrm{c})$ shows the variation of difference of 1961 and 1972, difference of 1988 and 1987 and difference of composite of surplus and deficient years during May over the four boxes for SWF, LHF and NHF. It shows that SWF in Box 1 and Box 2 is consistently negative i.e., during surplus years a lower magnitude of SWF is received. However, in Box 3 and Box 4, the anomalies of 1961 and 1972 and 1988 and 1987 are positive but in the composite pattern, the SWF difference is negative. The magnitudes are very small. The LHF and NHF are consistently positive and negative respectively in all the three categories and in all the boxes (figure $7 \mathrm{a}, \mathrm{b}, \mathrm{c})$. The LHF and NHF in Box 1 are the most dominant, indicating its higher response sensitiveness over the other boxes.

The SWF, LHF and NHF difference of 1961 and 1972, difference of 1988 and 1987 and difference of composite of surplus and deficient years during the monsoon season (JJAS) over four boxes are depicted in figure $7(\mathrm{~d}, \mathrm{e}, \mathrm{f})$. The variations in SWF in the monsoon season (JJAS) in different boxes indicate that Box 1 is consistently negative. Boxes 2, 3 and 4 show positive or negative variations and the magnitudes are very small. The LHF in Box 1 

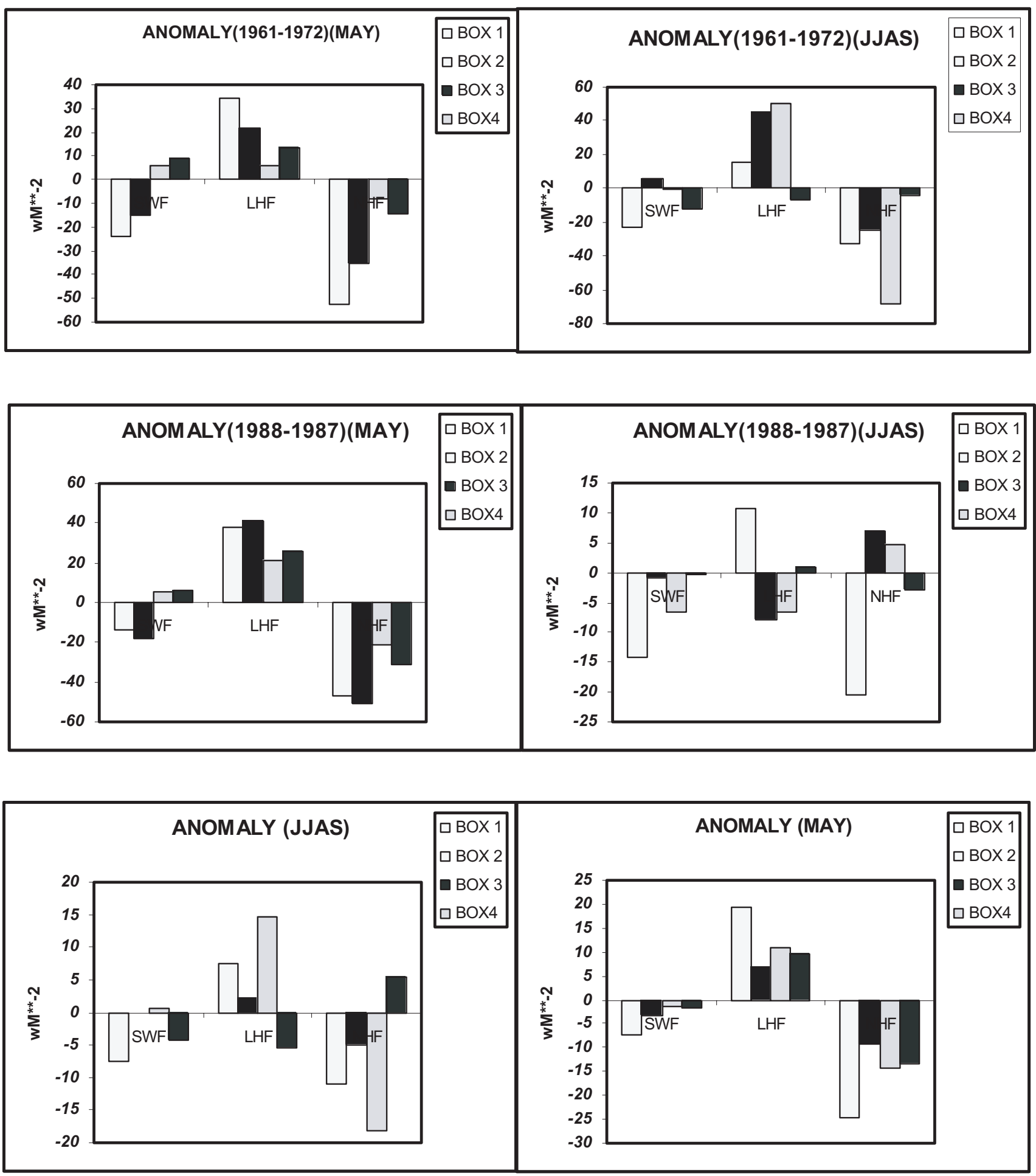

Figure 7. Variations of anomaly of SWF, LHF and NHF over Box 1, Box 2, Box 3 and Box 4 during May for (a) 1961 and 1972 (b) 1988 and 1987 (c) Composite of surplus and deficient years and (d), (e) and (f) are same as (a), (b) and (c) but for monsoon season (JJAS).

is positive in all the three categories. However, Box 2 and 3 show positive LHF difference in 1961-1972 and composite years, but negative in 1988-1987. Box 3 shows large variations. The pattern in Box 4 is opposite to that of Box 2 and 3. Thus, Box 1 shows consistent positive difference in the three categories, while Box 2 and 3 reverse sign in the post 1980 period (difference of the 1988 and 1987). The Box 4 magnitude is small. Box 3 anomalies though fairly large are not unidirectional.

The NHF difference in Box 1 is consistently negative in the three categories. Box 2 and 3 behavior 
is opposite in 1961-1972 and 1988-87. The behavior of Box 4 is opposite to that of Box 2 and 3. The NHF difference of Box 3 is large but is not unidirectional.

Thus, the region in Box 1 is very consistent in pre-monsoon as well as during the monsoon months to anomalies in SWF, LHF and NHF and remained unaffected in pre or post 1980 period. The area in Box 3 shows large variations in LHF and NHF, but is not consistent. It shows reversal in sign in 19881987. Box 2 behavior is similar to Box 3 but the magnitudes are smaller.

\section{Summary}

The mean sea level pressure difference is found to be significantly negative over major parts of India, Arabian Sea, Arabia and part of north Africa in the month of May as well as in the subsequent monsoon season. Positive anomalies of zonal wind at surface indicate that strong westerlies develop in the west Arabian Sea in the month of May. While, negative anomalies over Gangetic West Bengal indicate the establishment of a deeper monsoon trough line in May. Persistence of negative anomalies over the Indo-Gangetic plane in the monsoon season indicates the greater strength and persistence of the monsoon trough line in the surplus years. Significant southerlies at surface in the month of May indicates prevalence of northward transport, which in the present case could mean moisture. The stronger southerlies in the monsoon months of surplus years indicate higher northward transport of moisture. The positive difference of air temperature over northwest India during May is due to excess heating and the negative difference is due to excess clouding and possibly precipitation over northeast India. Significant negative anomalies are observed over the complete Indo-Gangetic plane indicating less insolation possibly due to excess clouding and precipitation during the monsoon season. Air temperature at $2 \mathrm{~m}$ shows similar pattern as surface temperature. The positive anomalies of cloud amount over south Indian Ocean across Somalia, Kenya, Arabian peninsula, north Arabian Sea and northwestern parts of India indicate that southeast trades in the southern hemisphere are stronger in the surplus years and after crossing the equator maintain their strength and vigor.

In the monsoon season, there is a NE-SW oriented band extending from Gangetic West Bengal northwest India to Arabia across north Arabian Sea, where significant reduction in SWF is observed. Another zone of significantly reduced SWF is a broken band oriented in east-west direction located in the south Indian Ocean between $5^{\circ} \mathrm{N}$ and $15^{\circ} \mathrm{S}$. The significant positive difference of LHF in May over southwest Arabian Sea may be considered as a useful advance indicator of the possible behavior of the subsequent monsoon season. There are significant regions of higher LHF located over part of Arabian Sea off Somali coast and south Indian Ocean off Madagascar during the monsoon season. The NHF in the month of May is significantly negative in the southwest Arabian Sea off Somali coast, south Indian Ocean off Madagascar and north Bay of Bengal. During the monsoon season of the surplus years, there is a significant region of NHF loss located over northwest India, northwest Bay of Bengal and adjoining Indian region, and south Indian Ocean equator to $20^{\circ} \mathrm{S}$.

Difference between two extreme monsoon years, one prior to 1980 (i.e., 1961 and 1972) and one post 1980 (i.e., 1988 and 1987) indicates reversal in sign, particularly in the south Indian Ocean of LHF and NHF. The SWF pattern shows eastward shift. The study of variation of heat budget component over four oceanic sectors shows that LHF and NHF during May and monsoon season in Arabian Sea (Box 1 ) is most dominant indicating its higher response compared to the other regions.

\section{Acknowledgements}

The authors wish to express sincere thanks to the National Centre for Environmental Prediction/National Centre for Atmospheric Research, U.S.A. for providing the necessary data sets. The authors also gratefully acknowledge the financial support from the Council of Scientific and Industrial Research to complete the work.

\section{References}

Das P K 1983 IMO Monograph on Monsoon, Fifth IMO Lecture Series, World Meteorological Organization, Geneva, $155 \mathrm{pp}$

Grassl H, Jost V, Kumar R, Schulz J, Bauer P and Schlüssel P 2000 The Hamburg Ocean-Atmosphere Parameters and Fluxes from Satellite Data (HOAPS): A climatological atlas of satellite-derived air-sea-interaction parameters over the oceans; Max-Planck-Report, $\mathbf{3 1 2} 130 \mathrm{pp}$

Josey S A, Kent E C and Taylor P K 1999 New insights into the ocean heat budget closure problem from analysis of the SOC air-sea flux climatology; J. Climate 12(9) 28562880

Kalney et al 1996 The NCEP/NCAR 40 years reanalysis project; Bull. American Met. Soc. 77 437-471

Kumar Krishna K, Balaji Rajagopalan and Mark Cane A 1999 On the weakening relationship between the Indian monsoon and ENSO; Science, 28 2156-2159

Manabe S, Bryan K and Spelman M J 1975 A global ocean atmospheric climate model. Part 1: the atmospheric circulation, J. Phys. Ocean 5 3-29 
Mohanty U C, Dube S K and Singh M P 1983 A study of heat and moisture budget over the Arabian Sea and their role in the onset and maintenance of summer monsoon; J. Meteorol. Soc. Jpn. 61 208-221

Mohanty U C and Mohan Kumar N 1990 A study of surface marine boundary layer fluxes over the Indian seas during different epochs Asian summer monsoon; Atmos. Environ. 24A 823-828

Mohanty U C and Ramesh K J 1993 Characteristics of certain surface meteorological parameters in relation to the interannual variability of Indian summer monsoon; Proc. Indian Acad. Sci. (Earth Planet Sci.) 102(1) 73-87

Mohanty U C and Ramesh K J, Mohan Kumar N and Potty K V J 1994 Variability of the Indian summer monsoon in relation to oceanic heat budget over the Indian seas; Dyn. Atmos. Oceans 21 1-22

Mohanty U C, Ramesh K J and Pant M C 1996 Certain seasonal characteristic features of oceanic heat budget components over the Indian seas in relation to the summer monsoon activity over India; Int. J. Climatol. $16243-264$
Parthasarthy B, Munot A A and Kothawale D R 1994 All-India monthly and seasonal rainfall series: 1987-1993 Theor. Appl. Climatol. 45 217-224

Pisharoty P R 1965 Evaporation from the Arabian Sea and Indian southwest monsoon; In: Proceedings of International Indian Ocean Expedition (ed) P R Pisharoty pp. $43-54$

Rao K G and Goswamy B N 1988 Interannual variations of the SST over the Arabian Sea and the Indian monsoon: a new perspective; Mon. Weather Rev. 116 558-568

Saji N H, Goswami B N, Vinayachandran P N and Yamagata T 1999 A dipole mode in the tropical Ocean; Nature 401 No. 6751, 360-363

Shukla J 1975 Effects of Arabian Sea surface temperature anomaly on Indian monsoon: A numerical experiment with GFDL model; J. Atmos. Sci. 33 503-511

Shukla J 1987 Interannual variability of monsoons: In: Monsoons (eds) J S Fein and P Stephens (Chichester: Wiley)

Weare B C 1979 A statistical study of the relationship between ocean surface temperatures and the Indian monsoon; J. Atmos. Sci. 36 2279-2291 